\title{
ART PERFORMANCE BUILDING IN GROBOGAN WITH A CLASSIC ARCHITECTURAL APPROACH GEDUNG PERTUNJUKAN SENI DI GROBOGAN DENGAN PENDEKATAN ARSITEKTUR KLASIK
}

\author{
Isma Mulya Hadi Wijaya' ${ }^{1)}$, Adi Sasmito ${ }^{2)}$, Anityas Dian Susanti ${ }^{3)}$ \\ Program Studi Arsitektur, Fakultas Teknik, Universitas Pandanaran Semarang \\ ismamulia18@ gmail.com ${ }^{1)}$ \\ adisas@unpand.ac.id ${ }^{2}$ \\ tyas@unpand.ac.id ${ }^{3)}$
}

\begin{abstract}
Abstrak
Adanya sebuah seni dalam kehidupan sehari-hari manusia merupakan bagian yang tidak bisa dipisahkan. Karena kesenian merupakan bagian dari budaya, dimana menjadi sarana guna untuk mewariskan budaya yang ada sejak zaman dahulu kepada seluruh penerus budaya atau masyarakat. Kemudian terdapat berbagai kegiatan kebudayan yang sekarang sudah modern dan mendominasi, sehinga kebudayaan lokal yang mengandung banyak sejarah sedikit terlupakan. Walau bagaimanapun kita sebagai penerus atau pewaris sudah masuk dalam perubahan teknologi dunia yang modern, tetapi harapannya juga tidak melupakan atau menghilangkan kebudayaan maupun kesenian yang terdahulu. Harapannya dapat terus melestarikan kebudayaan yang ada dan mengkolaborasikan dengan yang modern, sehingga dapat menjadikan sebuah pertunjukan yang sangat menarik. Maka dari itu dibutuhkannya wadah bagi para pelaku kesenian baik tradisonal dan modern guna untuk tempat berkumpul, latihan, dan juga pusat pertunjukan kesenian di Kabupaten Grobogan. Tujuan dari penyusunan ini sebagai hasil dari landasan konseptual perencanaan dan perancangan Gedung Pertunjukan Seni di Grobogan sebelumnya yang telah dibuat. Kemudian metode perancangan yang digunakan yaitu pendekatan aspek konseptual, pendekatan aspek fungsional, dan pendekatan aspek arsitektural. Konsep perancangan Gedung pertunjukan seni ini menggunakan pendekatan arsitektur klasik dengan menekankan bentuk fasad yang terdapat bayak ornamen pendukung konsep klasik itu sendiri, kemudian simetris atau tegas, penggunaan kolom yang besar dan tinggi. Sehingga nantinya akan menjadi pusat kegiatan seni bagi para pelaku seni khususnya di kab. Grobogan dan luar grobogan.
\end{abstract}

Kata kunci: Gedung Pertunjukan, Kesenian, modern dan tradisional, arsitektur klasik.

\begin{abstract}
The existence of an art in human daily life is an inseparable part. Because art is part of culture, which is a means to pass on a culture that has existed since ancient times to all the successors of culture or society. Then there are various cultural activities that are now modern and dominating, so that local culture that contains a lot of history is a little forgotten. Evan though we, as successors or heirs, have entered into the changing technology of the modern word, we hope that we will not forget or eliminate the provious culture and arts. The hope is that it can continue to preserve existing culture and collaborate with modern ones, so that I can make a very interesting show. Therefore, a forum for traditional and modern art actors is nede for a place to gathee, prectice, and performances in Grobogan Regency. The purpose of this arrangement as a result of the conceptual basis for planning and designing the performing arts building in Grobogan previously created. Then yhe design method used is the conceptual aspect approach, the functional aspect approach, and the arcitectural aspect approach. The design concept of this performing arts building uses a classical architectural approach by emphasizing the form of the façade which has many ornaments supporting the classical concept it self, then symmetrical or firm, the use of large and tall columns. So that later it will become the
\end{abstract}


center of art activities for art actors, especially in the district. Grobogan and outside grobogan.

Keywords: Performance Building, Art, Modern and Traditional, Classical Architecture.

\section{PENDAHULUAN}

Keberadaan seni dalam kehidupan sehari-hari manusia merupakan bagaian yang tidak bisa dipisahkan. Karena kesenian merupakan bagian dari budaya, dimana menjadi sebuah sarana guna untuk mewariskan budaya yang ada sejak zaman dulu kepada penerus budaya dan untuk masyarakat luas. Maka dari itu sangat perlu dibutuhkannya wadah atau tempat bagi para pelaku budaya dan kesenian baik tradisional dan modern, yang nantinya dapat digunakan untuk berkumpul, berlatih, dan menampilkan sebuah pertunjukan. Kemudian harapan dari perancangan gedung pertunjukan ini agar dapat menjadi sebuah icon kota dibidang seni. Gedung pertunjukan seni ini bertujuan untuk melihat hasil dari sebuah landasan konseptual perencanaan dan perancangan dalam sebuah bangunan pertunjukan didaerah Kabupaten Grobogan dengan pendekatan perancangan arsitektur klasik yang telah dibuat sebelumnya. Kemudian untuk manfaat perancangan ini secara subjektif adalah untuk memenuhi persyaratan kelulusan perencanaan tugas akhir jurusan S1 arsitektur universitas pandanaran semarang. Kemudian secara objektif adalah sebagai hasil pedoman dan acuan perancagan gedung pertunjukan seni di Grobogan yang telah dirancang sebelumnya. Lingkup pembahasan lebih pada berbagai hal yang berkaitan dengan perencanaan dan perancangan gedung pertunjukan seni yang ditinjau dari berbagai aspek ilmu arsitektur dengan dilengkapi ilmu diluar arsitektur yang dibahas seperlunya guna untuk mendukung pemecahan masalah yang ada. Kemudian batasan dalam perencanaan dan perancangan gedung pertunjukan seni ini dengan melalui pendekatan arsitektur klasik dan memenuhi syarat dari ciri klasik yang disebutkan, dan harapannya dapat menjadikan icon dan daya tarik untuk wisatawan. Terdapat tiga Preseden yang diambil yaitu 1. Royal Albert Hall
Inggris. 2. Aula Simfonia Jakarta. 3. Gedung Kesenian Jakarta.

\section{TINJAUAN TEORI}

Gedung pertunjukan seni merupakan sebuah bangunan gedung atau tempat yang memiliki fungsi untuk melayani dan memfasilitasi berbagai macam pertunjukan seni itu sendiri. Dimana faktor kenyamanan dan keamanan sangat diutamakan dalam perancangan gedung pertunjukan ini. Arsitektur klasik merupakan warisan sejarah peradaban barat yang berkembng sejak zaman yunani kuno, dimana ketika yunani kuno menjadi bangsa dengan peradaban paling maju diseluruh dunia. Kemudian kemegahan gaya arsitektur klasik ini meyebar keseluruh penjuru dunia. Arsitektur klasik ini memiliki ciri umum yang bayak terdapat pada bangunan, seperti adanya pilar-pilar besar berbentuk lengkung. Pilarpilar tersebut banyak terdapat di bagian atas pintu, atap kubah, puncak menara dan bagian lainnya. Hal tersebuat menjadi salah satu alasan mengapa gaya klasik masih banyak digunakan orang dalam perancangan bangunan adalah karena gaya ini terkesan mewah dan sifatnya abadi. Selain itu terdapat banyak ornamen unik dan rumit hampir disetiap sudut bangunan. Kemudian gaya arsitektur klasik ini juga banyak mengalami transformasi sehingga muncul beberapa cabang dari arsitektur klasik. Seperti arsitektur klasik yunani, arsitektur klasik romawi, arsitekur klasik italia, dan arsitektur klasik amerika. Pada perencangan ini lebih menekankan pada gaya arsitektur klasik romawi.

\section{METODOLOGI PERANCANGAN}

- Pendekatan Aspek Kontekstual. Pemilian lokasi terpilih dari analisa sebelumnya yang sudah dilakukan. 


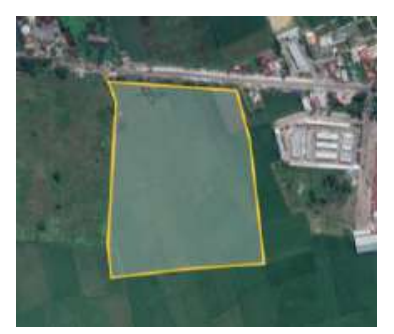

Gambar 1. Pemilihan Lokasi terpilih

Lokasi perancangan berada di jl. Gajah mada purwodadi dengan luas lahan $58.200 \mathrm{~m} 2$ dengan orientasi bangunan ke utara. Dengan batasan lahan :

Timur : Pasar Sayur Purwodadi

Selatan : Sawah / lahan kosong

Barat : Lahan Kosong

Utara : Jalan raya SMG - PWDD

Berdasarkan peraturan tentang peraturan bangunan, maka dapat diketahui sebagai berikut :

Program ruang terbentuk $: 13.100 \mathrm{~m} 2$

GSB $\quad: 1 / 212 \mathrm{~m}$ menjadi $6 \mathrm{~m}$.

KDB $40 \%: 23.280 \mathrm{~m}$

KLB : 2 Lantai

Hitungan tersebut yang berada pada tanah dengan luasan $58.200 \mathrm{~m} 2$.

A. Analisa Orientasi Matahari

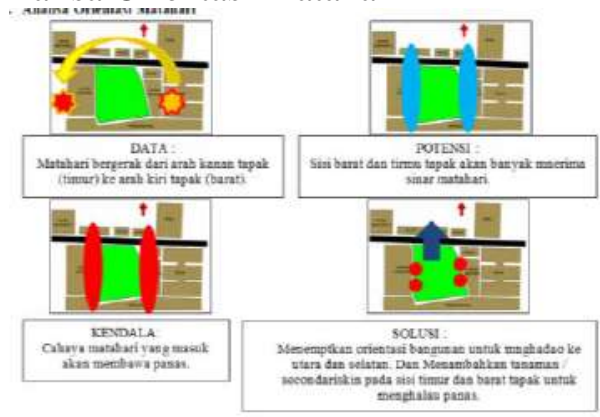

Gambar 2. Analisa Orientasi matahari

B. Analisa Arah angin

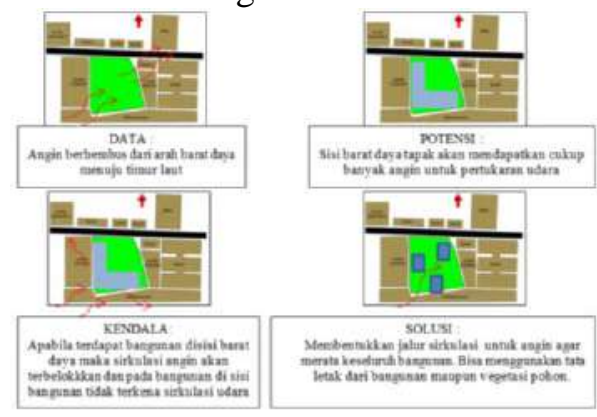

Gambar 3. Analisa Arah angin

C. Analisa Orientasi Tapak

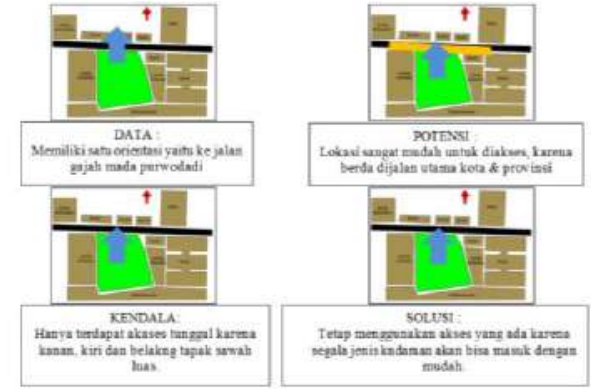

Gambar 4. Analisa Orientasi Tapak

\section{D.Analisa Sirkulasi}

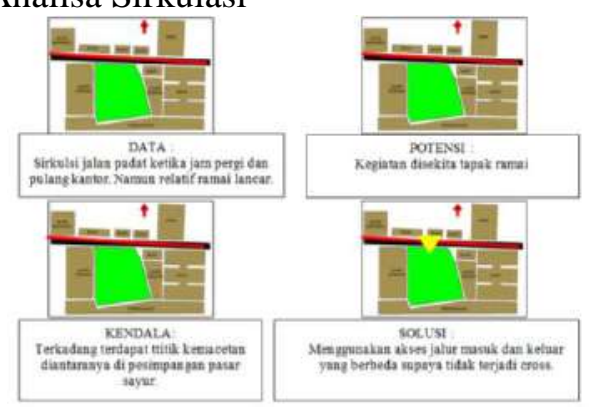

Gambar 5. Analisa Sirkulasi

E. Analisa Aksebilitas

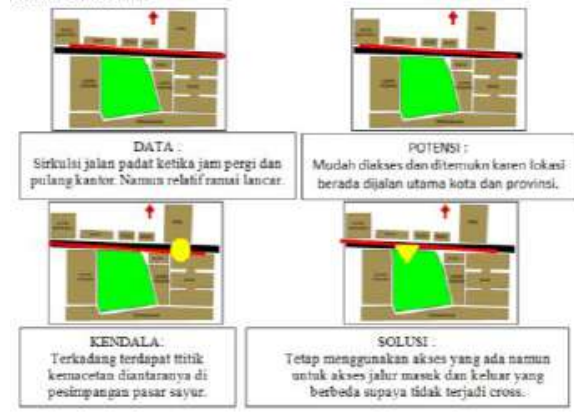

Gambar 6. Analisa Aksebilitas

F. Analisa Kebisingan

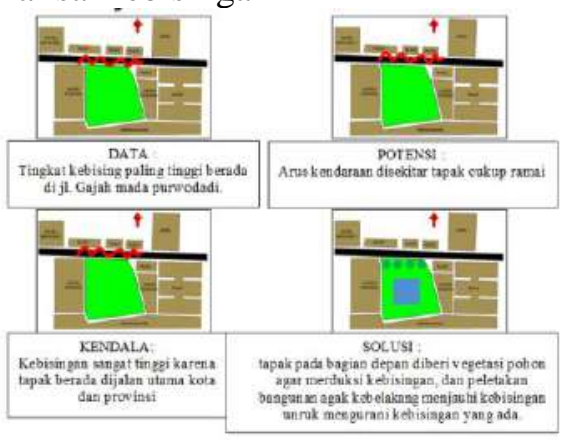

Gambar 7. Analisa Kebisingan

G.Analisa View 


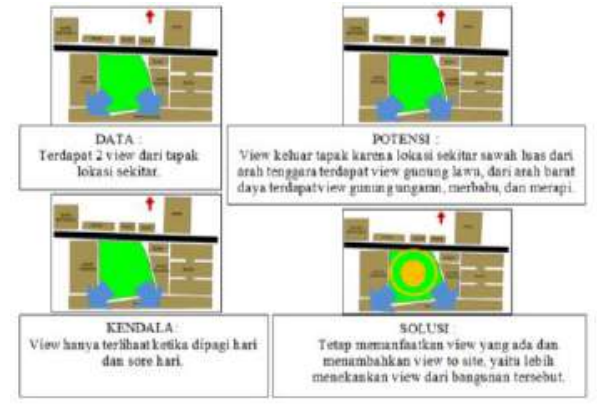

Gambar 8. Analisa View

H. Analisa Vegetasi

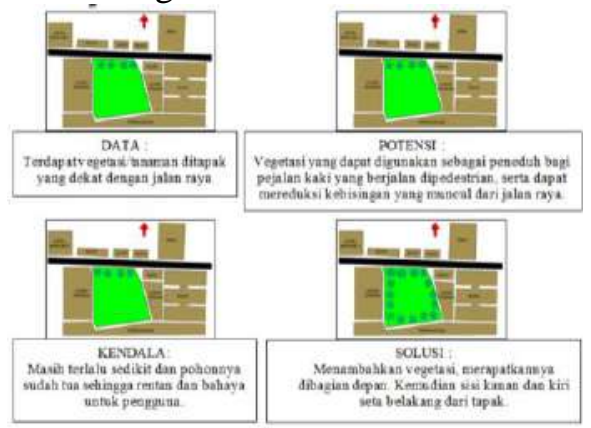

Gambar 9. Analisa Vegetasi

I. Analisa Drainase

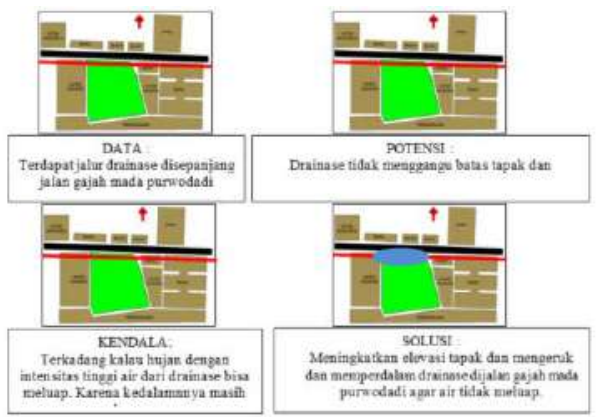

Gambar 10. Analisa Drainase

J. Analisa Tautan Lingkungan
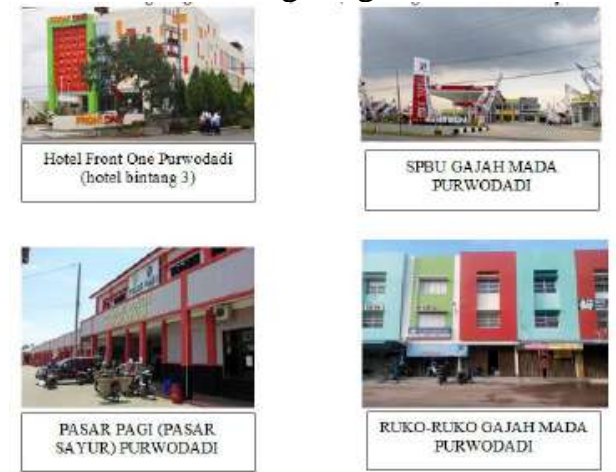

Gambar 11. Analisa Tautan Lingkungan
- Kelompok Pengunjung

- Kelompok Pengelola

- Kelompok Penampil

- Kelompok Penyelenggara

- Kelompok Media

\section{B. Program Kebutuhan Ruang}

\begin{tabular}{|c|c|c|c|}
\hline $\begin{array}{l}\text { KFIOSPOK } \\
\text { FASIIIAS }\end{array}$ & $\begin{array}{l}\text { PELAST } \\
\text { KECISTAN }\end{array}$ & AKTIVTAS & $\underset{\text { RUANG }}{\text { ITBUTHA }}$ \\
\hline \multirow{5}{*}{ PERTUNUTEAY } & PENCUNJUNC & 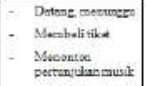 & 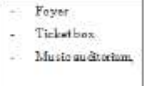 \\
\hline & PENASIPLL. & 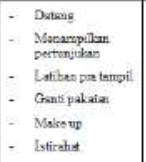 & 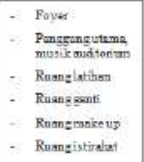 \\
\hline & PENYELENCCARA & 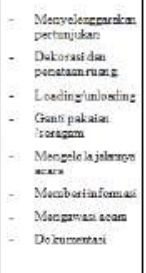 & 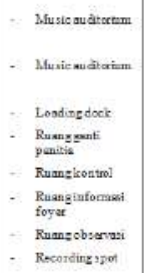 \\
\hline & PENCELOLA & 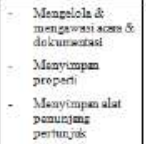 & $\begin{array}{l}\text { Ruangloutreal } \\
\text { Ruangeroperti } \\
\text { Cudang }\end{array}$ \\
\hline & PENCUNUING & 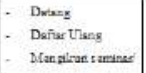 & 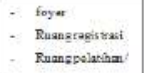 \\
\hline \multirow{3}{*}{$\begin{array}{l}\text { SEMINAR } \\
\text { WORKSHOP }\end{array}$} & & werking & saxinat \\
\hline & PENYELENGGARA & 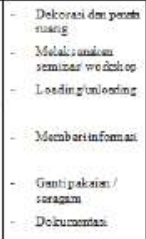 & 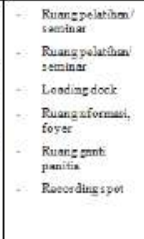 \\
\hline & PENCELOLA & 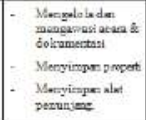 & 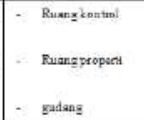 \\
\hline \multirow[b]{2}{*}{ KLPENCELOLAN } & $\begin{array}{l}\text { PENGUNUUNG \& } \\
\text { PENYLENGGARA }\end{array}$ & - moccari Ifformast & $\begin{array}{l}\text { rums monasti } \\
\text { nums trmes. }\end{array}$ \\
\hline & PENGELOLA & 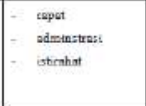 & 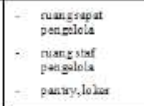 \\
\hline \multirow[t]{2}{*}{ PENUSAANG } & PENGTSUTYC & 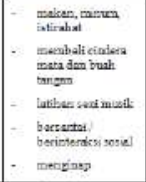 & 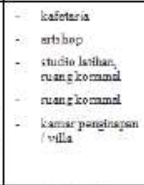 \\
\hline & PENYELENCG:ARA & 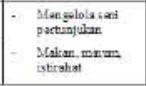 & 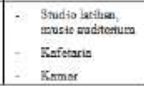 \\
\hline
\end{tabular}

- Pendekatan Aspek Fungsional

A. Program Aktivitas

Pelaku : 


\begin{tabular}{|c|c|c|c|}
\hline & & - Dostzatep & petizingyan ville \\
\hline & PENGELOLA & 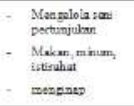 & 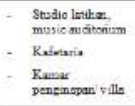 \\
\hline \multirow{4}{*}{ SERVICE } & PENCUNJUNC & 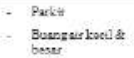 & 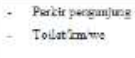 \\
\hline & $\begin{array}{c}\text { PENASTIL } \\
\& \\
\text { YENYNINGCARA }\end{array}$ & 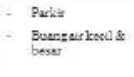 & 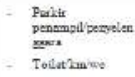 \\
\hline & PENGELOLA & 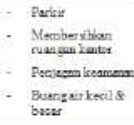 & 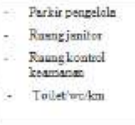 \\
\hline & Eates & - Kogtar lasin lax & 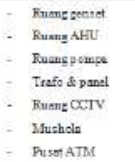 \\
\hline
\end{tabular}

\section{Program Besaran Ruang}

- Besaran Ruang Studio Latihan

Tabel 2. Total Studio Latihan

\begin{tabular}{|c|c|}
\hline PROGRAMREAVG STWPIO LATHAY & TOLAL LASAX (OR? \\
\hline BACLANUTAM & 12800 \\
\hline BACLAY PENUNANG & 29200 \\
\hline BAGIAV SERVIS & sse.20 \\
\hline TOTAL & L.193.:0 \\
\hline
\end{tabular}

- Besaran Ruang Auditorium

Tabel 3. Total Ruang Auditorium

\begin{tabular}{|c|c|}
\hline PROGRAVIRLASG MICSIK ACTMTORTIM & TOTALUASAY OEZ) \\
\hline BAGLAY ULAMA & sase.00 \\
\hline BACLAX PESUNJASO & 1550.06 \\
\hline BAGLAX SERVIS & 598.06 \\
\hline TOTAL & 3.478 .06 \\
\hline
\end{tabular}

- Besarab Ruang Pengelola

Tabel 4. Total Ruang Pengelola

\begin{tabular}{|c|c|}
\hline 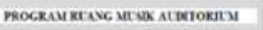 & 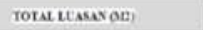 \\
\hline Bachs UTAMA & 700.06 \\
\hline 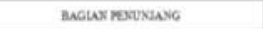 & 3900.09 \\
\hline Mactas exprss & wase \\
\hline TOTA. & 4901.90 \\
\hline
\end{tabular}

- Besaran Ruang Parkir

Tabel 5. Service Ruang Pengelola

\begin{tabular}{|c|c|c|c|c|c|c|}
\hline JWESTEANC & $\begin{array}{l}\text { KAPASTLS } \\
\text { POKLYG) }\end{array}$ & 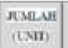 & 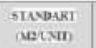 & rasarer & 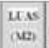 & 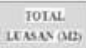 \\
\hline Pevowent & 40 & 1 & $\begin{array}{c}120 \\
\text { sxxเusias. }\end{array}$ & $S R P$ & 500 & sout \\
\hline $\begin{array}{l}\text { Monf } \\
\text { rexotian }\end{array}$ & 10 & 1 & \begin{tabular}{c|c|}
120 \\
$\sin 20 t+512 x$
\end{tabular} & $\begin{array}{l}150 \\
54\end{array}$ & 1512 & 15i: \\
\hline MOTOR & 130 & 1 & 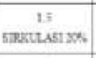 & $\begin{array}{l}\text { Dre } \\
54\end{array}$ & 20 & 370 \\
\hline sos & 10 & 1 & $\begin{array}{c}10 \\
\text { sxactuss ax }\end{array}$ & $\begin{array}{ll}\mathrm{SRg} \\
\mathrm{SA}\end{array}$ & 198 & 292 \\
\hline \multicolumn{6}{|c|}{ stes Totat } & 12410 \\
\hline \multicolumn{6}{|c|}{ SITREITAST MN } & 9654 \\
\hline \multicolumn{6}{|c|}{ Tots } & 180.10 \\
\hline \multicolumn{6}{|c|}{ Dв:LARAX } & 18940 \\
\hline
\end{tabular}

REKAPITULASI

PROGRAM RUANG

Tabel 6. Service Ruang Pengelola

\begin{tabular}{|c|c|}
\hline mesismotxar & TOTALLLASAVMI) \\
\hline STrbo LATIIAS & 100300 \\
\hline AlDitom & $5.78 . .00$ \\
\hline Krevevetiotanx & 490100 \\
\hline maxis & 1.584 .60 \\
\hline ЛТЕСН TOTAL. & 13.066 .00 \\
\hline Disthankas & 13.100 .50 \\
\hline
\end{tabular}

D. Program Persyaratan Ruang

Tabel 7. Service Ruang Pengelola

\begin{tabular}{|c|c|c|c|c|c|c|c|c|c|}
\hline \multirow{3}{*}{ No. } & \multirow{3}{*}{ Nama Ranne } & \multicolumn{8}{|c|}{ KFBUTUHAN } \\
\hline & & \multicolumn{2}{|c|}{ Peuceshassean } & \multicolumn{2}{|c|}{ Penghawaan } & \multicolumn{2}{|c|}{ Koneanan } & \multicolumn{2}{|c|}{ Alustilik } \\
\hline & & $=$ & salua & theri & $=0=$ & 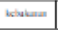 & 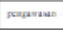 & $=$ & $=$ \\
\hline \multicolumn{10}{|c|}{ FASIITAS PERTUNJUKAN } \\
\hline 1. & R Foyet & 1 & 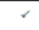 & 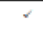 & - & 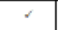 & r & r & \\
\hline 2. & R Tizize box & 1 & $r$ & & r & & 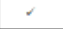 & 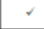 & \\
\hline 3. & Muxic Anditerium & & 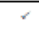 & & s & & - & & $\mathrm{s}$ \\
\hline 4. & Lobby & 1 & 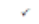 & $\checkmark$ & - & s & 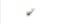 & r & \\
\hline s. & $\mathbb{R}$ Letiben & & r & & 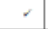 & & 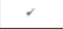 & & . \\
\hline 6. & R Garn & & 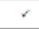 & & 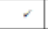 & & 5 & 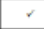 & \\
\hline 7. & R. Mato U O & & r & & - & & - & r & \\
\hline 8. & R. Itisirahat & 1 & 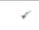 & 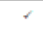 & - & & - & & - \\
\hline 9. & Louding Doek & 1 & 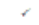 & 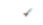 & & 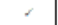 & & 1 & \\
\hline 10. & R Kentrol & & 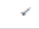 & & $\checkmark$ & r & & 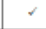 & \\
\hline 11. & R. Observai & & $\checkmark$ & & 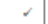 & & - & $\sigma$ & \\
\hline 12. & Fecording $\mathrm{S} p o t$ & & 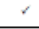 & 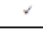 & 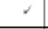 & 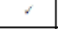 & & 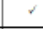 & \\
\hline 13. & R. Properti & & r & & 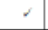 & & 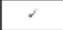 & - & \\
\hline 14. & Goden: & & 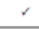 & & 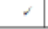 & & 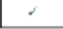 & r & \\
\hline \multicolumn{10}{|c|}{ FASLITAS SEMINAR / WORKSHOP } \\
\hline 1. & Lobby & 1 & ' & . & r & $s$ & - & - & \\
\hline 2. & R. Reatrasti & & 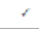 & & - & & - & + & \\
\hline 3. & $\begin{array}{l}\mathrm{R} \\
\text { Poolutihan: Seminarer }\end{array}$ & & r & & - & & - & & . \\
\hline 4. & Losding Dock & 1 & 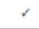 & 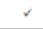 & . & 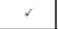 & 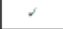 & 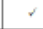 & \\
\hline s. & R. Foyer & 1 & - & $r$ & 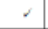 & 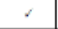 & 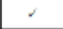 & + & \\
\hline 6. & R. Gams & & s & & - & & - & - & \\
\hline 7. & R. Kontrol & & 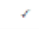 & & - & & 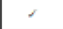 & 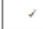 & \\
\hline 8. & Racording Spor & & 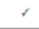 & 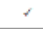 & s & 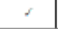 & 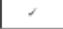 & + & \\
\hline 9. & R. Properti & & 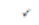 & & s & & $\checkmark$ & $\checkmark$ & \\
\hline 10 & Gudan: & & s & & s & & $\checkmark$ & $\checkmark$ & \\
\hline \multicolumn{10}{|c|}{ FASIITAS KEPENCELOLAAN } \\
\hline 1. & R. Informesi & & $r$ & $r$ & 8 & & $\checkmark$ & $r$ & \\
\hline 2. & R. Tamus & 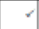 & 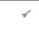 & & s & & r & 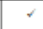 & \\
\hline 3. & R Rapat & o & 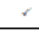 & & 8 & & $r$ & & 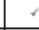 \\
\hline 4 & R. Staff & 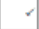 & r & & s & & - & & ? \\
\hline 5. & R. Panyy & & r & & 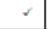 & & r & 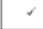 & \\
\hline \multicolumn{10}{|c|}{ FASUITAS PENCXJANC } \\
\hline 1. & Keffotaria & 1 & r & r & 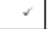 & r & r & s & \\
\hline 2. & Artsbop & 7 & 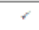 & 1 & 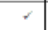 & 1 & 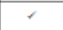 & 1 & \\
\hline 3. & Studio Lathan & 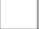 & r & & . & & 1 & & 1 \\
\hline 4. & R. Komunal & 1 & - & & . & & ' & 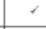 & \\
\hline s. & Pengirapers / Villa & 1 & 1 & 1 & 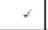 & 1 & 1 & & 1 \\
\hline \multicolumn{10}{|c|}{ FASLITAS SERVICE } \\
\hline 1. & Pachir & 1 & $r$ & ' & . & & 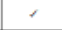 & 1 & \\
\hline 2. & Tollet / wC & & - & & . & & 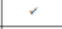 & $r$ & \\
\hline 3. & R. fanitess & & 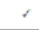 & & s & & 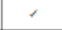 & - & \\
\hline 4. & $\begin{array}{l}\text { R. Rentrol } \\
\text { Kovamanes }\end{array}$ & 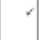 & r & & r & & $r$ & 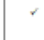 & \\
\hline s. & R Gonst & 1 & 1 & 1 & & 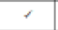 & '́ & + & \\
\hline 6. & R AHV & $v$ & $r$ & $r$ & & r & r & r & \\
\hline 7. & R. Pormon & 1 & 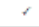 & ' & & 1 & 1 & 1 & \\
\hline 8. & Travo \& Punel & 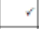 & $r$ & $r$ & & $r$ & r & $r$ & \\
\hline 9. & Mathols & 1 & 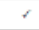 & 1 & s & & 1 & & 1 \\
\hline 10. & ATM Conter & $y$ & c & & s & $r$ & $r$ & $r$ & \\
\hline & & & & & & & & & \\
\hline
\end{tabular}

E. Program Sirkulasi dan Hubungan Ruang.

- Sirkulasi Pengunjung 


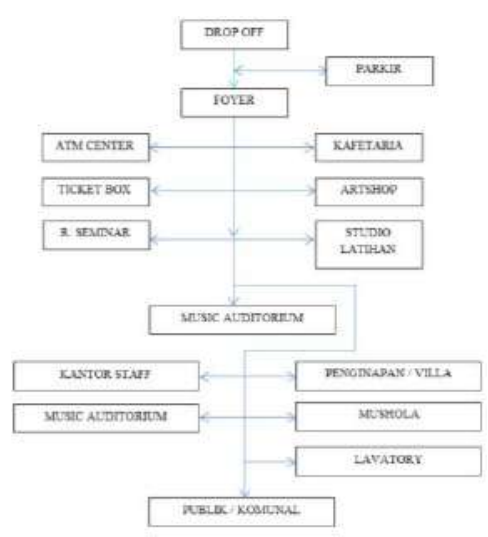

Diagram 1. Sirkulasi Pengunjung

- Sirkulasi Penampil

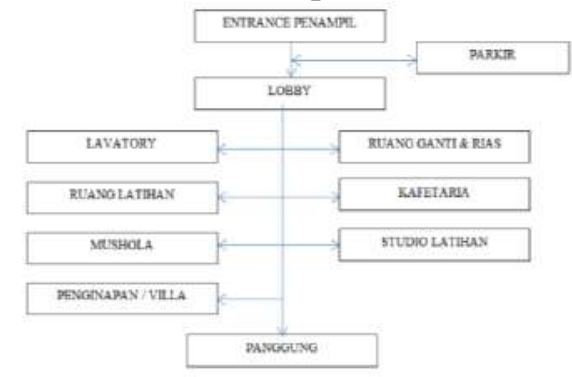

Diagram 2. Sirkulasi Penampil

- Sirkulasi Penyelenggara

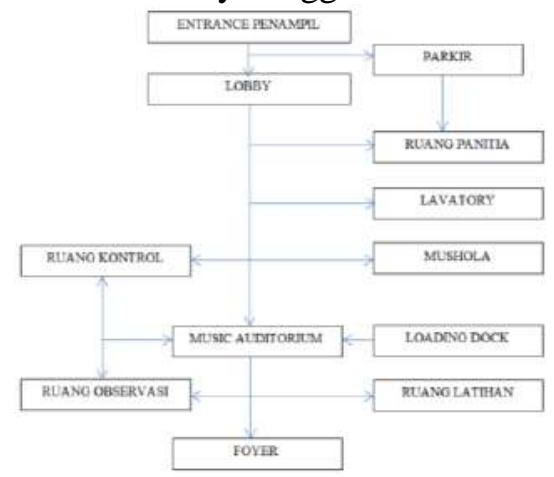

Diagram 3. Sirkulasi Penyelenggara

- Sirkulasi Pengelola

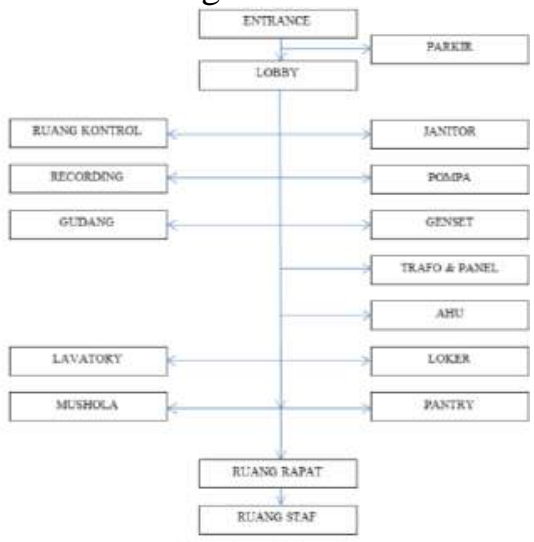

Diagram 4. Sirkulasi Pengelola
- Sirkulasi Barang

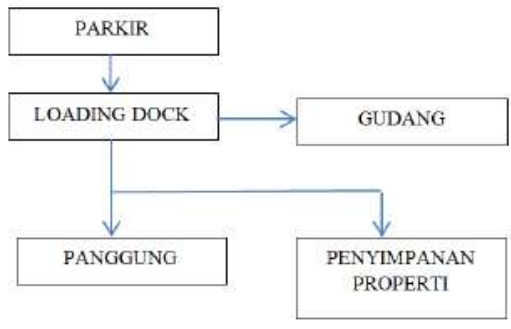

Diagram 5. Sirkulasi Barang

\section{- Hubungan Ruang}

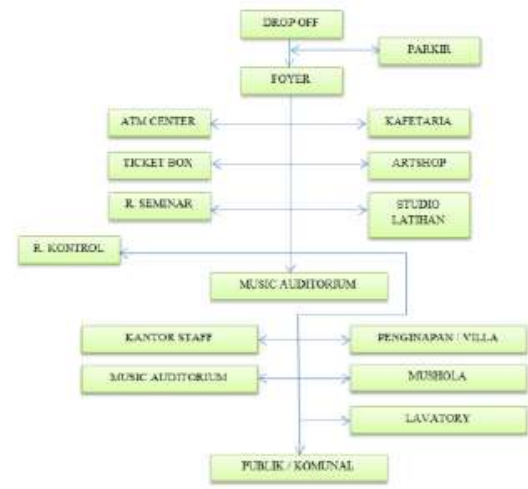

Diagram 6. Hubungan Ruang

\section{F. Program Massa Bangunan}

Pemilihan program massa bangunan yang akan diterapkan diharapkan dapat memberikan kemudahan, efisiensi terhadap fungsi serta dapat merspon kondisi lingkungan disekitar site. Kemudian terdapat dasar dan kriteria yang harus dipertimbangkan :

- Kondisi tapak serta lingkungan.

- Jenis aktivitas serta sifat ruang.

- Bentuk arsitektural yang merespon terhadap kondisi lingkungan.

Bentuk Dasar Massa Bangunan

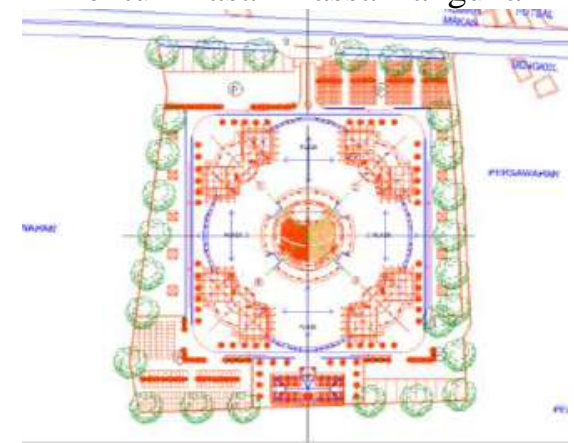

Gambar 12. Dasar Massa Bangunan 
- Segi empat / Bujur sangkar

- Bentuk yang netral, memiliki arah dari segala sisi, terkesan formal, solid.

- Memungkinkan efisien dalam pemakaian ruang.

- Memungkinkan luas dalam bergerak.

- Terkesan kaku dan monoton.

- Lingkaran

- Mempunyai bentuk yang dinamis.

- Mempunyai pandangan ke segala arah.

- Keluasan bergerak.

- Efisien ruang tidak cukup baik.

- Kombinasi

Penggabungan dari beberapa bentuk dasar segi empat yang presisi sehingga menjadkan bentuk baru untuk massa bangunan.

Penentuan bentuk massa bangunan gedung pertunjukan seni ini adalah bermassa banyak. Muncul dari beberapa bentuk dasar dan beberapa kombinasi yang dimainkan. Selain itu memberikan penghuninya agar dapat lebih leluasa dalam mengekspose ruang, kemudian juga melihat dari bentuk site agar saling sinkron antara massa bangunan dengan bentuk site.

Pemilihan Tata Massa Bangunan

Pola tatanan yang akan digunakan untuk perancangan gedung pertunjukan seni ini adalah pola simetri dan grid. Dimana massa dari masing-masing gedung pertunjukan diletakakn dengan selaras dan simetris dan dipadukan dengan grid.

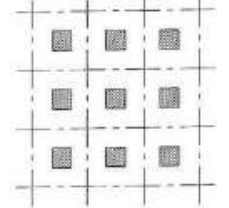

Gambar 13. Pola Massa Bangunan

- Pendekatan Aspek Arsitektural

Konsep perancangan ini menggunakan pendekatan arsitektur klasik pada setiap desain bangunannya. Bentuk fasad yang terdapat banyak ornamen dan penggunaan kolom-kolom besar sebagai tiang utama. Pendekatan aspek ini dapat dibagi menjadi tiga aspek yaitu massa bangunan, ketinggian bangunan, dan bentuk bangunan.

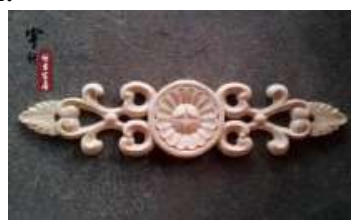

Gambar 14. Detail Ornamen Bangunan

Terdapat poin penting yang menjadi tolok ukur terbentuknya aspek arsitektural :

- Warna yang dominan pada bangunan akan menciptakan suasana pada bangunan

- Potensi lokasi terpilih dimaksimal kan dengan penataan bangunan yang baik.

- Ruang luar dan ruang dalam tertata dengan baik sehingga ada sinergi antar ruangan.

- Fungsi bangunan dan konteks lingkungan merupakan dasar dari penerapan tema bangunan.

- Pesan-pesan yang ingin disampaikan melalui wujud fisik bangunan.

- Detail bangunan diperhatikan sehinga dapat dinikmati oleh pengunjung.

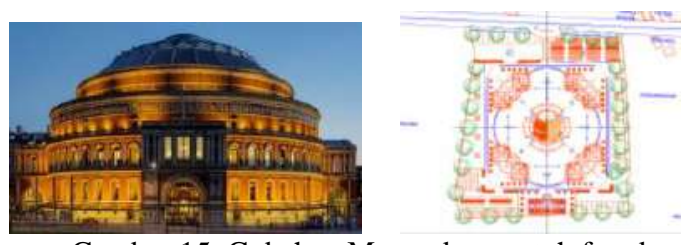

Gambar 15. Gubahan Massa dan contoh fasad

\section{PEMBAHASAN}

A. Konsep Tapak

1. Konsep Tata Letak

Perencanaan tapak dibuat untuk menanggapi analisa tapak pada pembahasan sebelumnya. Berdasarkan analisa maka tata letak bangunan akan berada di kanan dan kiri, kemudian tengah tapak sebagai plaza. 


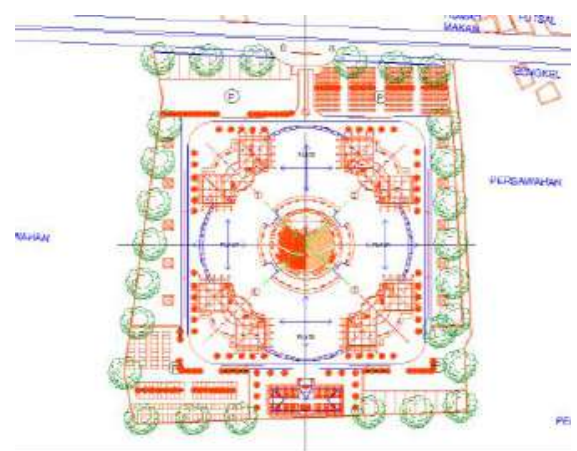

Gambar 16. Konsep Tata Letak

Dasar pertimbangann :

- Kesesuaian dengan karakter kegiatan yang majemuk dan heterogrn.

- Kemudahan membedakan tiap kelompok aktivitas (tingkaat kekomplekkan kegiatan)

- Kemudahan dalam pengontrolan dan pengelolaan operasional kegiatan.

- Kemudahan pelaksanaan aktivitas pertunjukan.

Perencanaan tapak dibuat untuk menanggapi analisa tapak yang sudah ada. Berdasarkan analisa maka letak massa bangunan akan menjadi beberapa bangunan sesuai dengan kondisi fungsi dan tapak.

2. Konsep Pencapaian

- Akses masuk dan keluar berada pada sisi utara site atau berada pada jalan utama,. Namun dipisahkan untuk mengindari cross antara pengunjung masuk dan pengunjung keluar.

- Berada dibagian paling dekat dengan jl. Gajah mada purwodadi sehingga mudah dicapai oleh pengunjung.

- Memaksimalkan sirkulasi jalan raya untuk menghindari cross.

Penerapan Konsep Pencapaian terhadap Site :

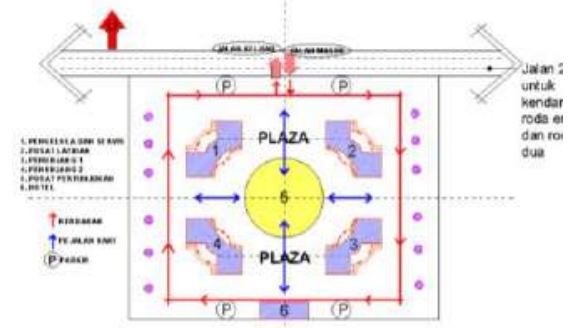

Gambar 17. Konsep Pencapaian
3. Konsep View

- View dari luar di konsep untuk menghadap ke jl. Gajah mada purwodadi sehingga dapat mengekspose bangunan untuk menarik perhatian pengunjung.

- Sekeliling site diberi pagar pembatas yang aman dan supaya memberikan kesan surprize terhadap orang luar.

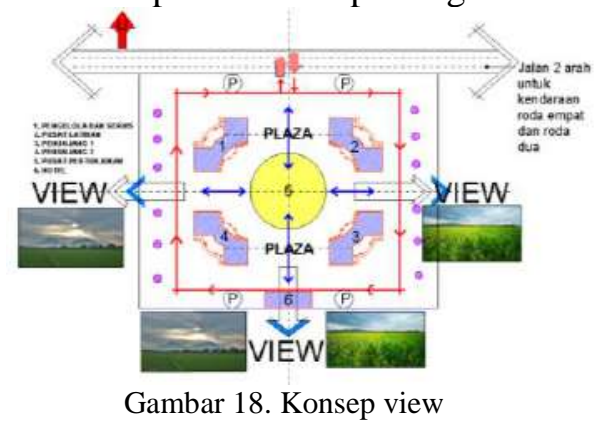

4. Konsep Kebisingan

- Penempatan bangunan diposisikan lebih kedalam atau jauh dari jalan raya.

- Penggunaan pagar pembatas dan vegetasi guna untuk mereduksi bangunan dari kebisingan disekitar terutama dari jalan raya.

- Kendala dari kebisingan juga bisa diatasi dengan menggunakan sistem zoning, fasilitas yang tidak membutuhkan ketenangan, serta fasilitas penunjang diletakkan dekat dengan zona bising sehingga dapat berfungsi sebagai barier terhadap fasilitas yang membutuhkan ketenangan dan privasi tinggi.

- Ruang uang memerlukan ketenangan dilatakkan menjauh dari sumber kebisingan.

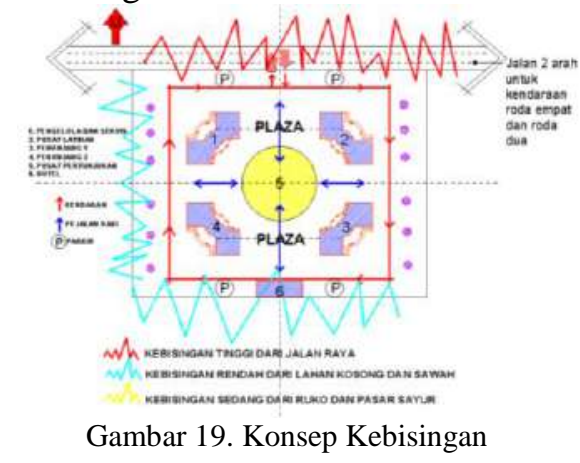


5. Konsep Matahari

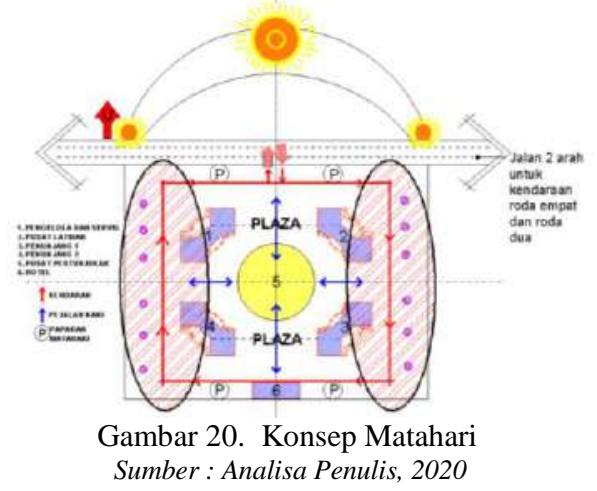

- Penghalang sinar matahari yang berlebihan menggunakan pepohonan untuk mereduksi sinar matahri serta penyaring polusi dari jalan raya.

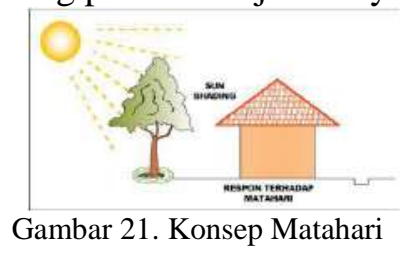

6. Konsep Angin

- Penambahan penataan vegetasi sebagai salah satu upaya membelokkan arah angin dengan tujuan mengurangi beban angin pada bangunan dana juga sebagai upaya memberikan kenyamanan.

- Menerapkan cross ventilaton untuk mendistribusikan udara yang bersih ke dalam ruangan.

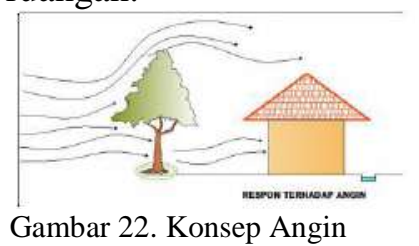

7. Konsep Sirkulasi

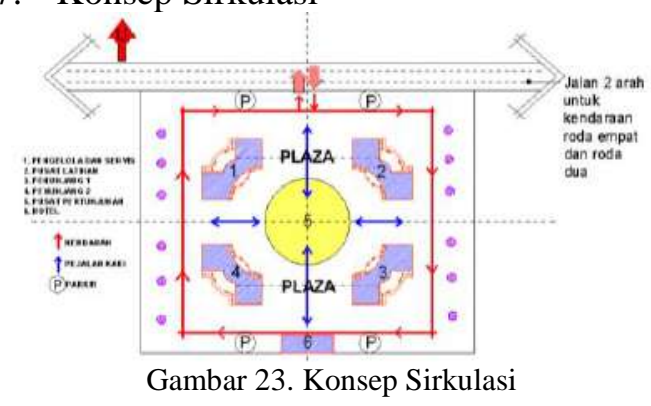

Dasar Pertimbangan :

- Kemudahan dalam pola hubungan pelayanan.

- Menghindari pola persilangan antara pengunjung dan pengelola pada bagian massa yang utama.

- Mencegah timbulnya kebisingan dan polusi udara yang diakibatkan oleh sirkulasi.

\section{B. Konsep Gubahan Massa}

1. Bentuk Dasar

Bentuk site ini seperti persegi panjang namun tidak sempurna dimana didalamnya terdapat 5 zona ruang yang muncul dari aktivitas yang diwadahi. Bentuk dari massa bangunan tersebut menyesuaikan dan dapat dikembangkan lagi bedasarkan faktor-faktor yang mempengaruhi massa bangunan.

2. Zoning

- Pemisah antara zona publik, semi publik, dan privat kedalam bentuk berzoningan ruang dan bangunan.

- Zona publik diletakkan dibagaian paling utara dan selatan dekat dengan area jalur pintu masuk dan pintu keluar.

- Zona semi publik diletakkan dibagian tengah site dekat dengan pintu masuk.

- Zona privasi diletakkan dibagian utara tapak dekat dengan side entrance dan diantara zona publik dan semi publik.

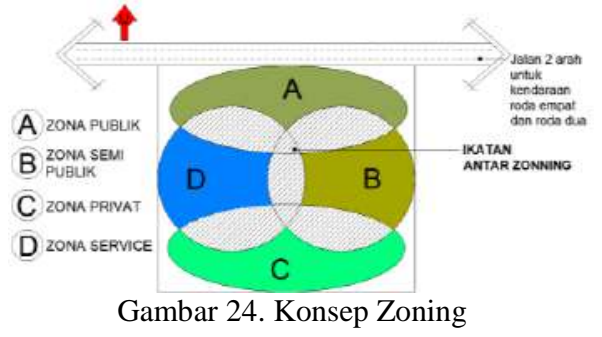

3. Konsep Orientasi Bangunan

Berdasrkan analisa yang sudah ada maka view bangunan menghadap ke utara mengarah ke jalan raya. Arah bangunan / orientasinya terhadap sinar matahari yaitu dengan menghadapkan bangunan ke arah utara dan selatan untuk menghindari intensitas sinar matahari yang berlebihan dari arah barat dan timur. 


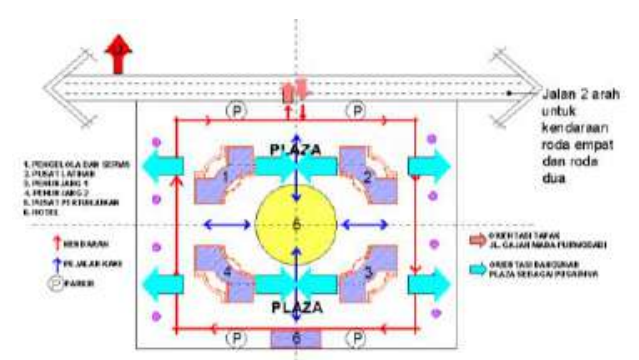

Gambar 25. Konsep Orientasi Bangunan

\section{Konsep Gubahan Massa}

Gubahan massa bangunan yang dipilih adalah massa variasi dan banyak dengan mengunakan pola penataan gubahan massa Grid dan Simetris. Pengambilan bentuk gubahan massa diperoleh dari :

1. Alat musik khas grobogan yang digunakan untuk mengiringi festival boyong grobog / perpindahan pusat kota Grobogan, yaitu kenong.

2. Grobog merupakan peti kotak besar yang dihiasi dengan ukiran-ukiran diluarnya yang digunakan sebagai tempat menyimpan senjata/barang pusaka, perhiasan, wayang,dll. Kata grobog ini sendiri merupakan sebutan nama sebelum terbentuknya nama kabupaten grobogan.

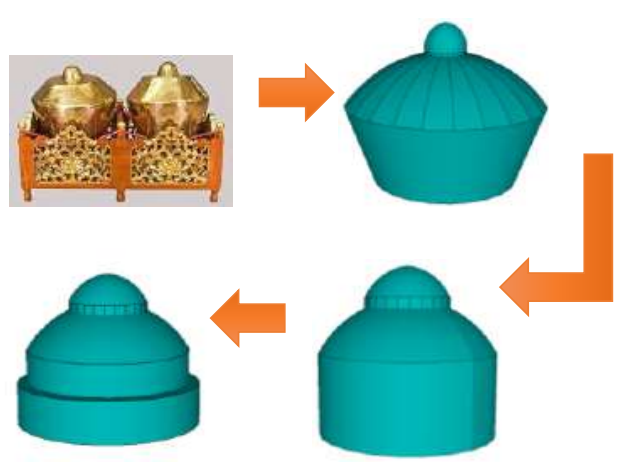

Kenong akan di implementasikan sebagai gubahan massa utama yaitu pusat pertunjukan seni. Dengan melalui sedikt trasformasi.

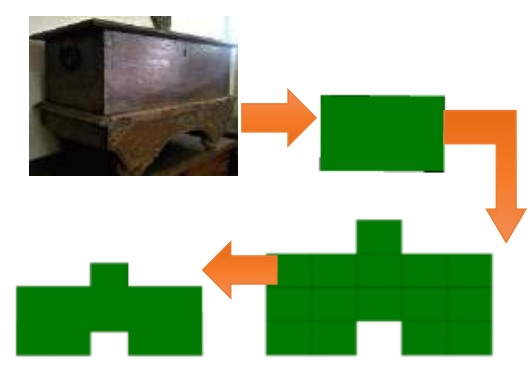

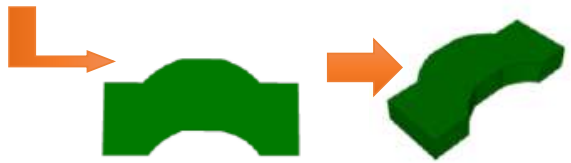

Grobog akan di implementasikan sebagai empat gubahan massa penunjang yang mengelilingi gubahan massa utama secara simetris, namun akan dikombinasikan terlebih dahulu agar menjadi satu kesatuan massa yang selaras dan simetris.

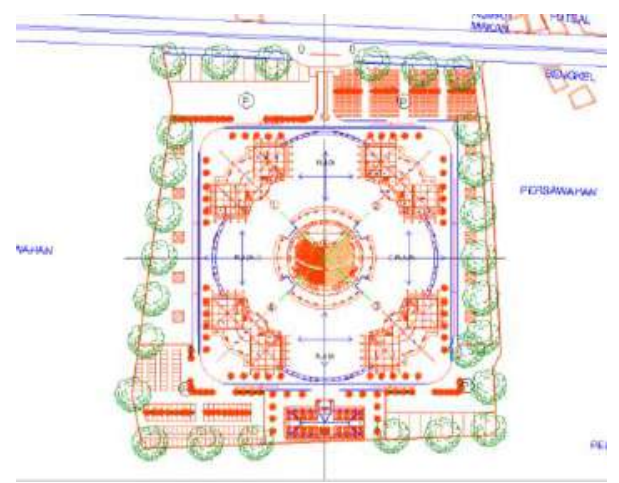

Gambar 26. Konsep Gubahan Massa

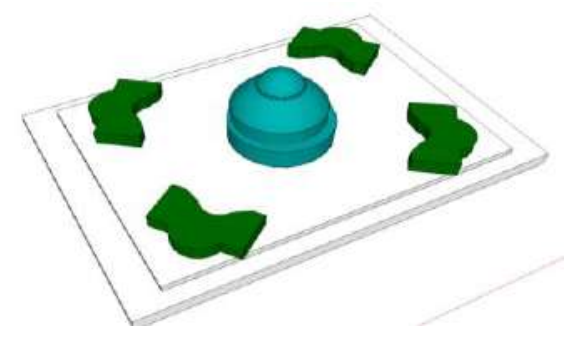

Gambar 27. Konsep Gubahan Massa

Terbentuknya penataan gubahan massa tersebut diperoleh dari analisis laparan dan data yang diperoleh dari penelitian dan dipadukan dengan pola penataan massa bangunanan yaitu pola Grid dan Simetris.

5. Konsep Penghijauan

Penghijauan pada lahan untuk menciptakan iklim mikro disekitar massa bangunan, dimana pada lingkungan sekitar massa bangunan diusahakan tercipta udara segar yang dihasilkan oleh pepohonan dan juga membantu dalam pencapaian sirkulasi diluar bangunan. Serta menjadi filter 
dari kebisingan dan polusi udara dari jalan sekitar tapak.

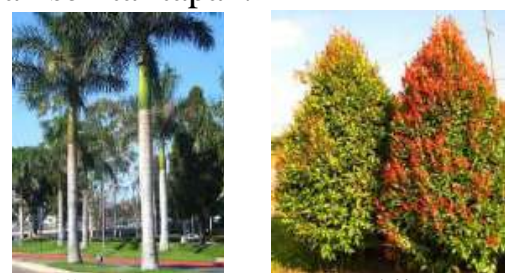

Gambar 28. Konsep Penghijauan

6. Konsep Visual Arsitektur

Terdapat poin penting yang menjadi tolok ukur terbentuknya aspek arsitektural :

- Warna yang dominan pada bangunan akan menciptakan suasana pada bangunan

- Potensi lokasi terpilih dimaksimal kan dengan penataan bangunan yang baik.

- Ruang luar dan ruang dalam tertata dengan baik sehingga ada sinergi antar ruangan.

- Fungsi bangunan dan konteks lingkungan merupakan dasar dari penerapan tema bangunan.

- Pesan-pesan yang ingin disampaikan melalui wujud fisik bangunan.

- Detail bangunan diperhatikan sehinga dapat dinikmati oleh pengunjung.

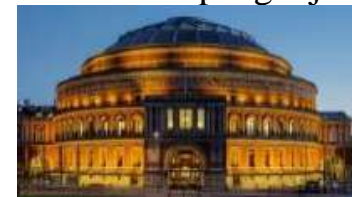

Gambar 29. Konsep Visual Arsitektur

Kemudian bentuk fasad dikombinasikan dan dengan menekankan detailnya atau ornamen-ornamen untuk mempercantik fasad bangunan.

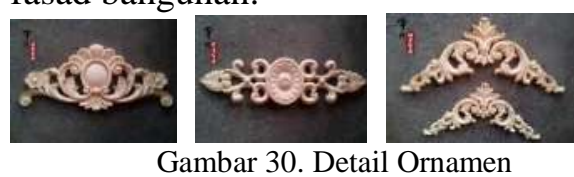

7. Konsep Ruang

- Konsep eksterior bangunan

- Drainase

- Jalur hijau

- Lampu penerangan

- Tempat duduk

- Pagar pengaman

- Tempat sampah

- Marka, rambu, dan papan informasi
- Perencanaan lansekap.

Semua hal tersebut sangatlah diperhatikan agar dapat memberi kesan nyaman dan tetunya juga terlihat menarik.

- Konsep Interior Bangunan

Bgitu juga interior agar menunjang segala aktifitas di gedung pertunjukan terdapat beberapa hal yang sangat perlu diperhatikan dalam penataan ruang dalam, yaitu:

- Keserasian/harmoni

- Irama dan proporsi

- Kesinambungan

- Kesatuan langgam dan gaya.

8. Konsep Struktur dan Konstruksi

- Sub Struktur

Berupa pondasi yang berada pada bagian bawah pondasi atau di dalam tanah. Tedapat dua jenis pondasi yang digunakan dalam perencanaan yaitu pondasi tiang pancang dan foot plat.

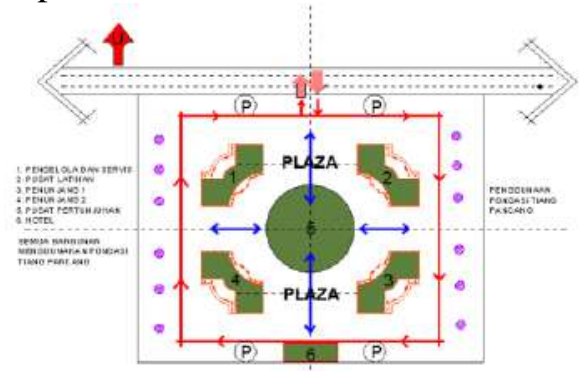

Gambar 31. Konsep Struktur dan Konstruksi

- Super Struktur

Berupa kolom, dinding, plafond guna untuk menyalurkan gaya-gaya ke sistem struktur bangunan.

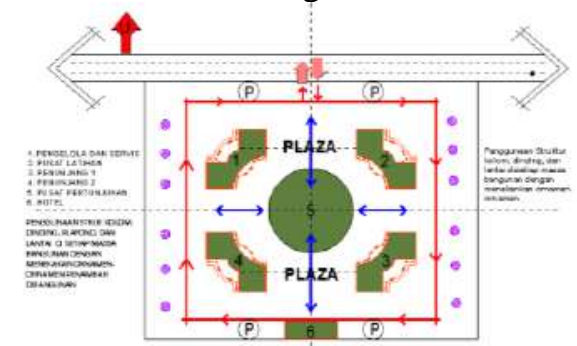

Gambar 32. Konsep Struktur dan Konstruksi

- Upper Struktur

Berupa struktur bangunan yang berada di atas kolom, dinding dan balok. Menggunakan rangka space frame dan bitumen cti. Dimana dalam gedung pertunjukan 
dibutuhkan bentangan yang sangat lebar. Serta pada bangunan penunjang menggunakan struktur baja ringan, dak, dan bitumen cti.

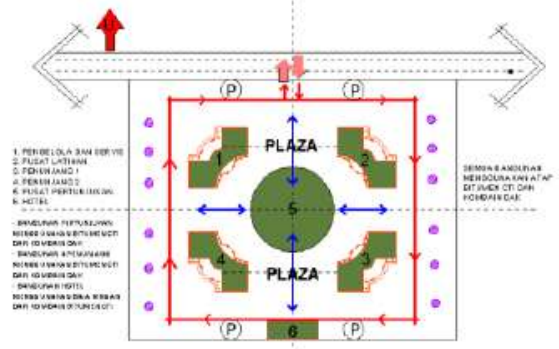

Gambar 33. Konsep Struktur dan Konstruksi

- Konstruksi dan Bahan Bangunan Untuk menciptakan suasana klasik, maka menggunakan material beton, kaca, kayu, dan batu, serta terdapat ornamen-ornamen yang selaras dan senada, agar konsep klasik dapat tertanam dengan kental. Maka dari itu sangat di perlukan untuk fasad bangunan.
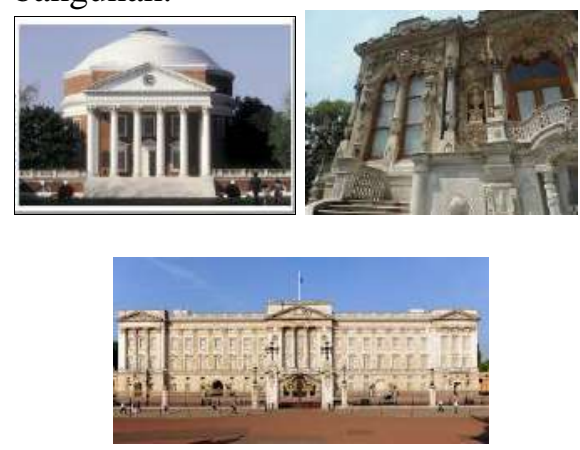

Gambar 34. Konsep Struktur dan Konstruksi

9. Konsep Utilitas

- Jaringan Air Bersih

Penggunaannya ialah sistem tangki tekan. Cara kerjanya adalah dimana air yang telah ditampung dala tangki bawah dipompakan kedalam suatu bejana (tangki) tertutup sehingga udara di dalamnya terkompresi. Kemudian air dari bejana tersebuat di alirkan ke dalam sistem distribusi bangunan masing-masing. Dimana pompa bekerja secara otomatik yang diatur oleh detektor tekan air itu sendiri.

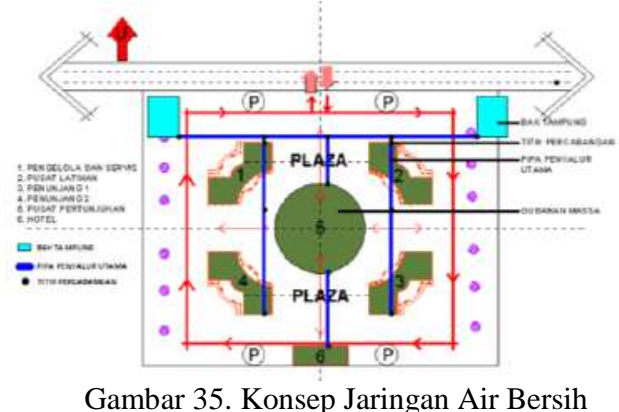

- Jaringan Air Kotor

A. Grey Water

Air kotor dari limbah cucian, kamar mandi, dan wastafel yang akan ditampung ke bak penampung sementara yang kemudian di filter ke dalam bak tampung akhir . dan hasil filteran ini dapat digunakan kembali untuk kebutuhan air dibagunan, perawatan lansekap, dan sumber untuk fire hydrant.

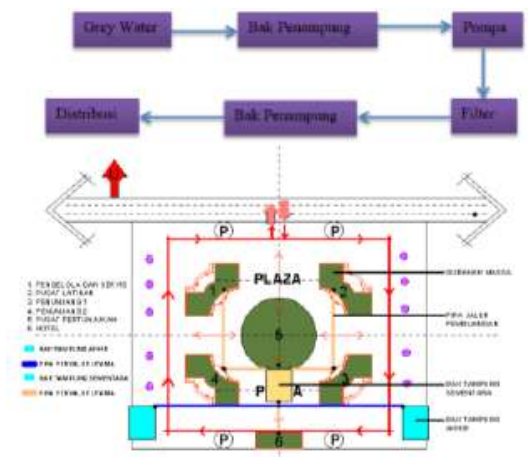

Gambar 36. Konsep Grey Water

B. Black Water

Air kotor atau limbah dari kotoran manusia yang nantinya ditampung dan difilter kemudian dibuang diresapan.

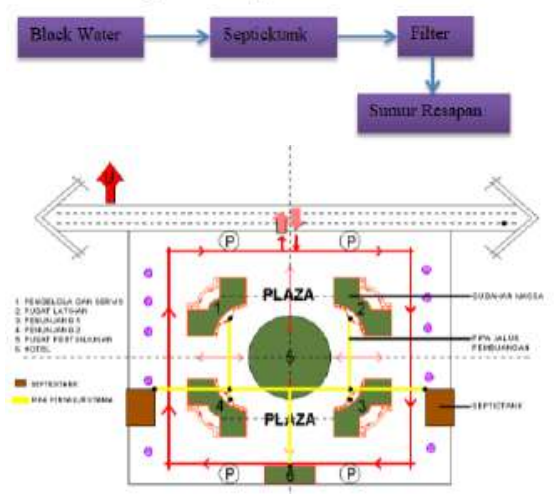

Gambar 37. Konsep Black Water 


\section{Air Hujan}

Begitu juga dengan air hujan yang kemudian ditampung dan dapat digunkan kembali.

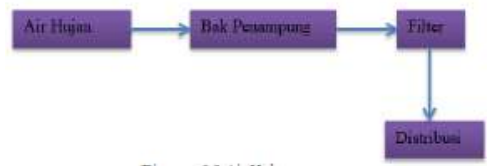

Gambar 38. Konsep Air Hujan

- Sumber listrik

Menggunakan PLN, Panel Surya, dan Genset Sebagai dopping atau cadangan.

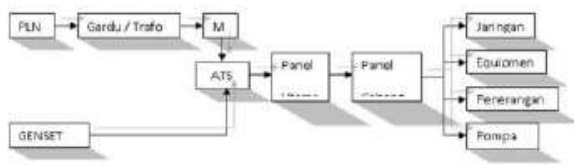

Gambar 39. Konsep Sumber Listrik

- Sistem Kebakaran

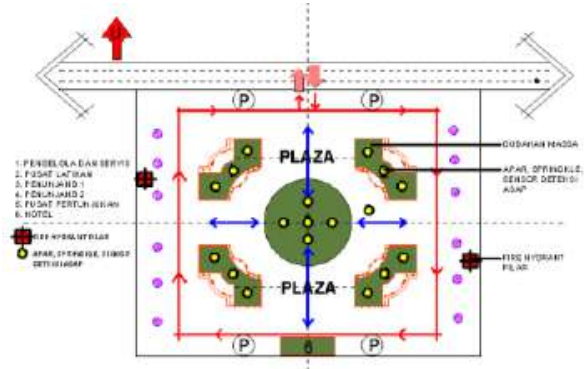

Gambar 40. Konsep sistem kebakaran

- Apar di letakkan di setiap sudut ruang tertentu dan menyebar ke semua gubahan massa.

- Fire hydrant di letakkan di dekat sumber air bak tampung akhir dari pengolahan grey water.

- Springkel dan deteksi asap terdapat disetiap ruangan dalam masa bangunan.

- Sistem Penangkal Petir

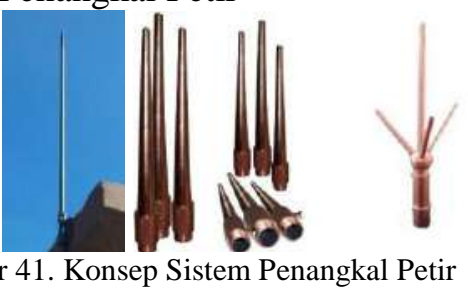

- Sistem keamanan

Menggunakan dua sitem keamanan adalah keamanan manual dengan adanya satpam yang berjaga 24 jam.
Dan keamanan teknologi dengan memasangkan CCTV disetia sudut ruangan.

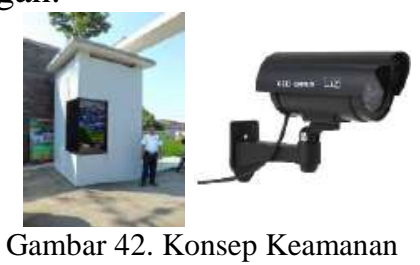

- Sitem akustik

Berguna untuk mereduksi kebisingan baik dari luar dan dalam bangunan, kemudan untuk mengisolir ruangan. Untuk penggunaan massa bangunannya adlah gedung pertunjukan atau auditorium itu sendiri.

\section{KESIMPULAN}

Bedasarkan penelitian yang telah dilakukan sesuai data dan fakta lapangan dan proses perancangan sebelumnya yang berprogres, dan sehingga terbentuknya sebuah perancangan lanjutan dari Analisa awal, konsep, hingga ke penerapan perancangan desain arsitektur. Dan berikut ini merupakan semua hasil dari proses perancangan akhir desain arsitektur gedung pertunjukan seni di Grobogan dengan pendekatan arsitektur Klasik.

Meliputi :

1. Gambar Kerja

2. Gambar Perspektif Eksterior

3. Gambar Perspektif Interior
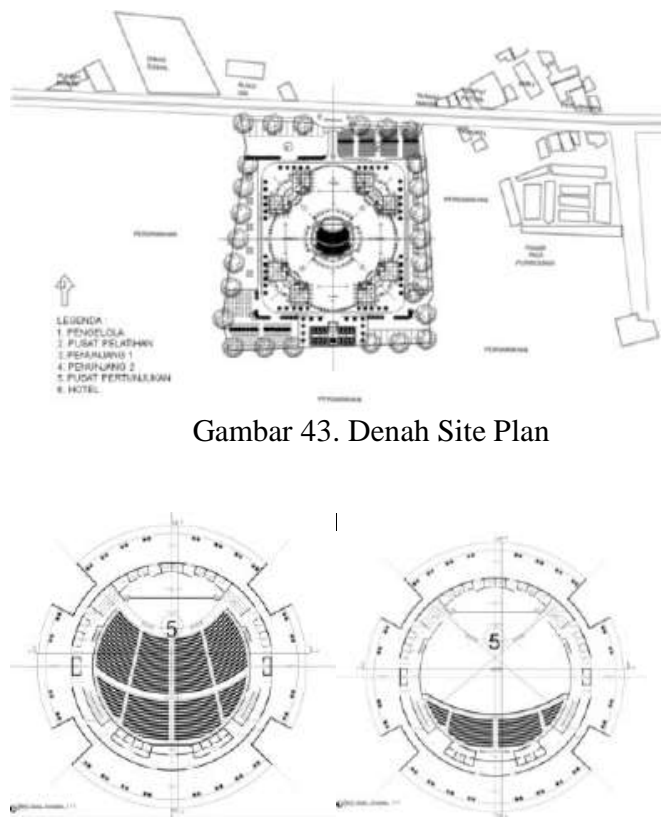


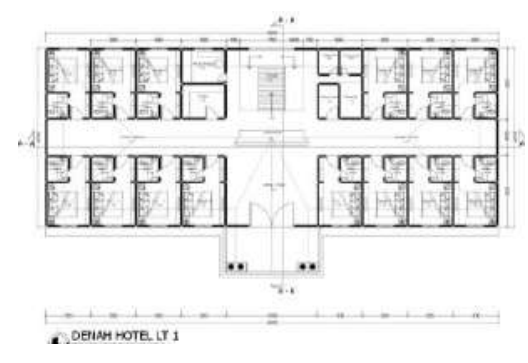

Gambar 45. Denah Hotel LT 1

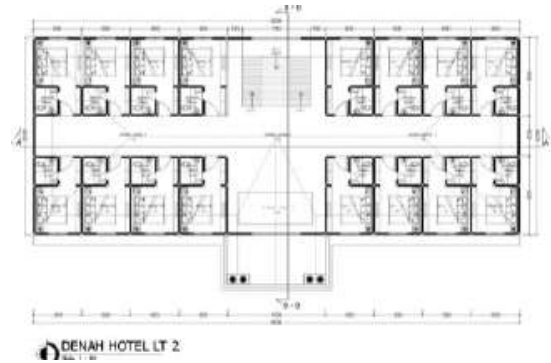

Gambar 46. Denah Hotel LT 2
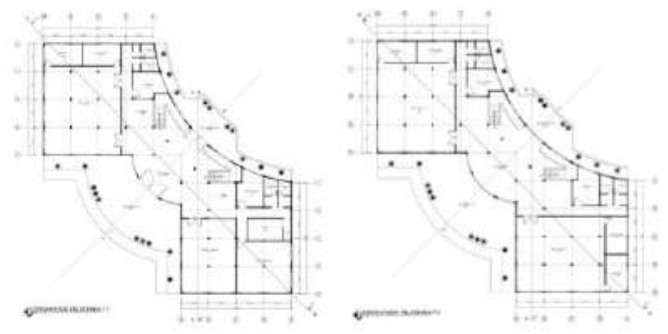

Gambar 47. Denah Gedung Pelatihan LT $1 \& 2$
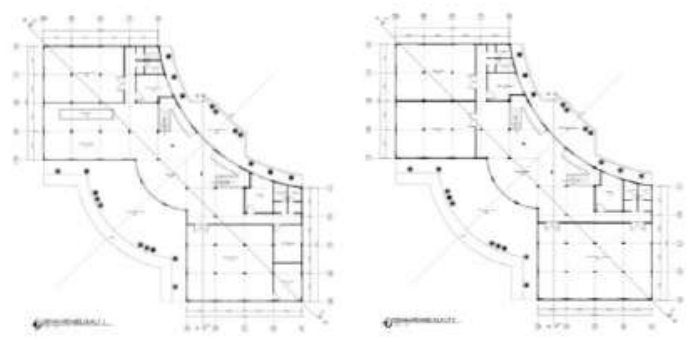

Gambar 48. Denah Gedung Pengelola LT 1\& 2
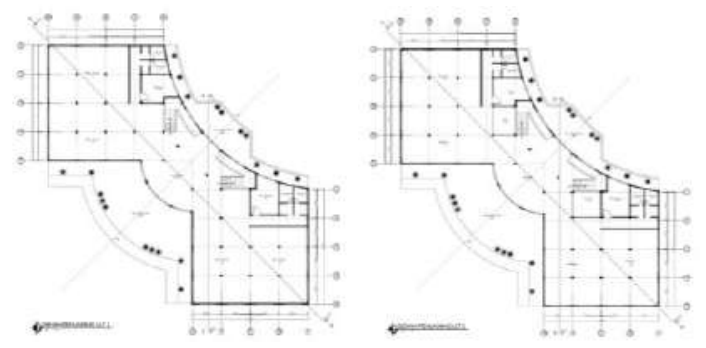

Gambar 49. Denah Gedung Penunjang 1 LT $1 \& 2$
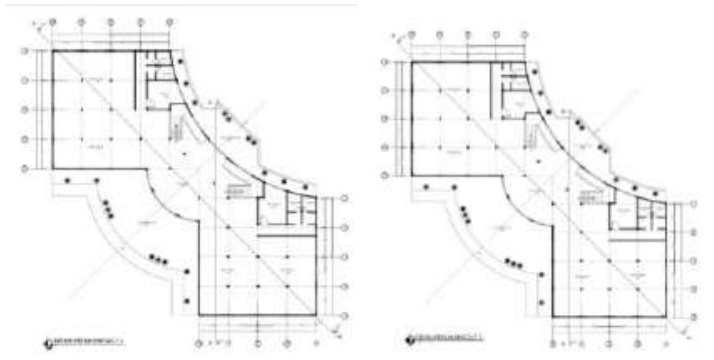

Gambar 5.8 Denah Gedung Penunjang 2 LT 1\& 2

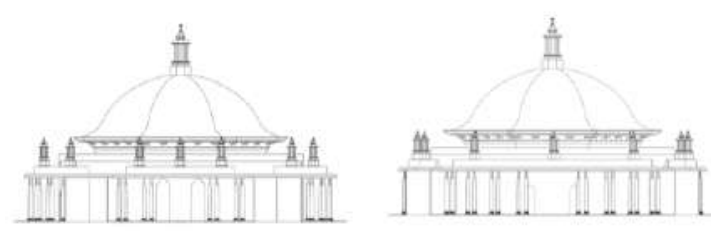

Gambar 50. Tampak Gedung Pertunjukan

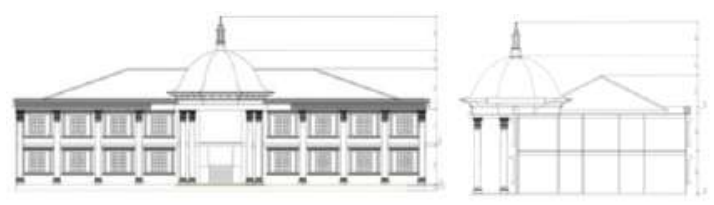

Gambar 51. Tampak Hotel

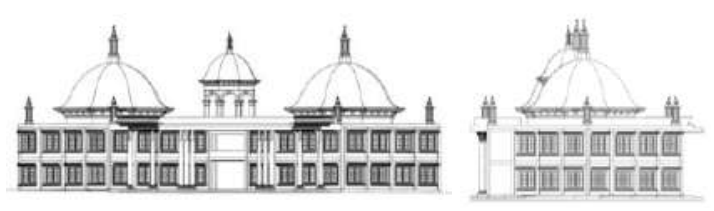

Gambar 52. Tampak Gedung Penunjang

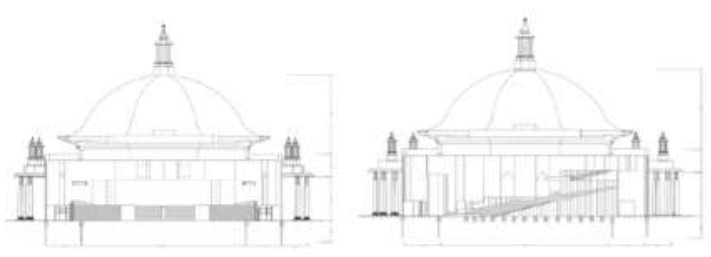

Gambar 53. Potongan Gedung Pertunjukan

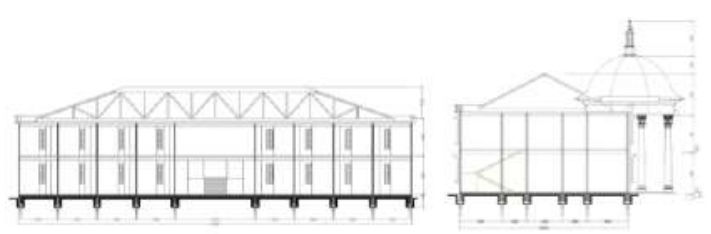

Gambar 54. Potongan Hotel

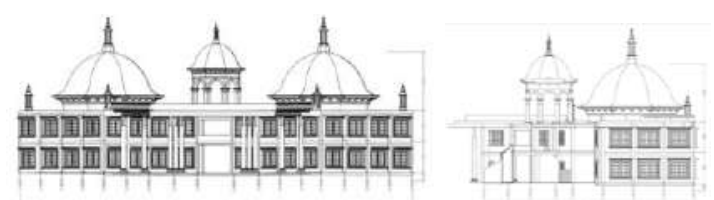

Gambar 55. Potongan Gedung Penunjang 


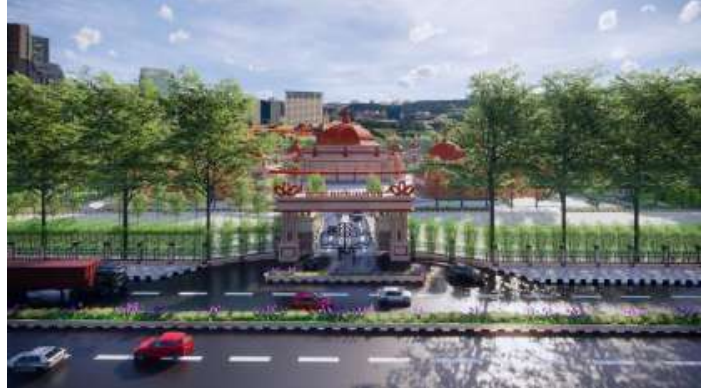

Gambar 56. Perspektif Eksterior

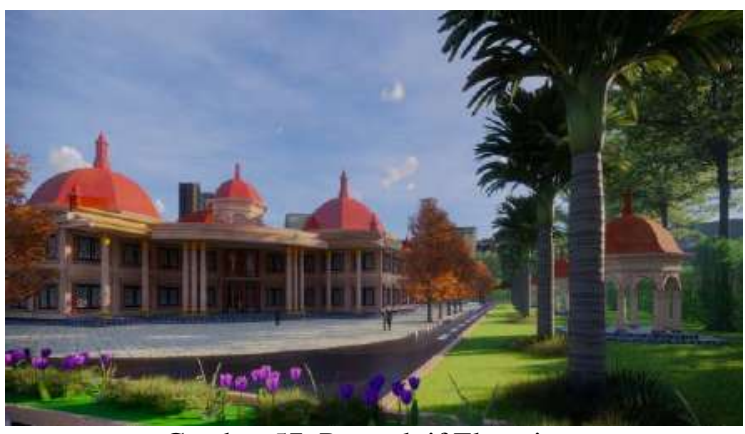

Gambar 57. Perspektif Eksterior

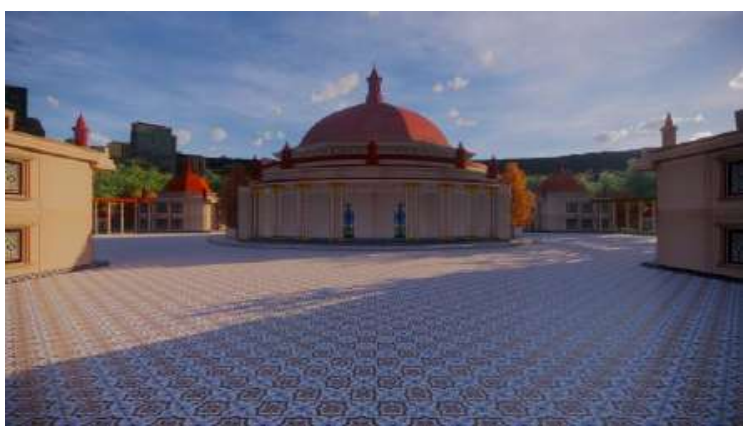

Gambar 58. Perspektif Eksterior

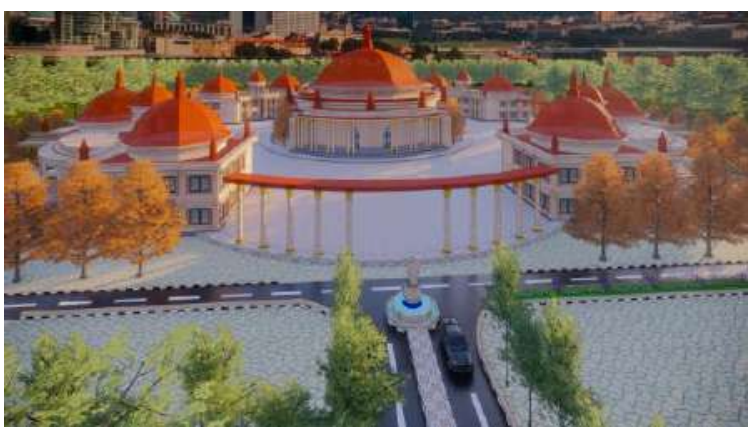

Gambar 59. Perspektif Eksterior

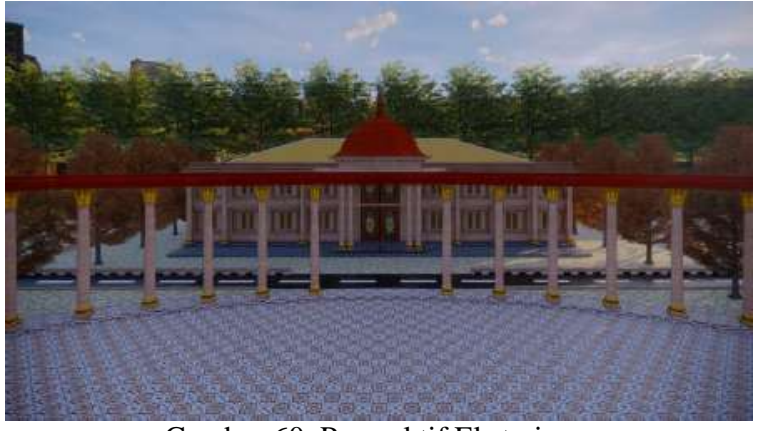

Gambar 60. Perspektif Eksterior

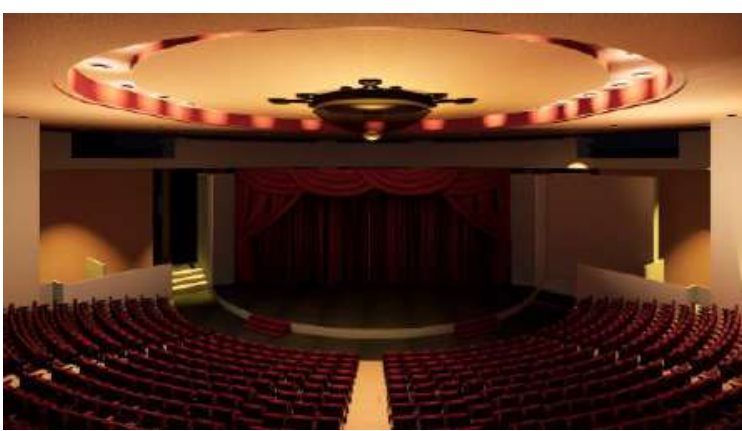

Gambar 61. Perspektif Interior Gedung Pertunjukan

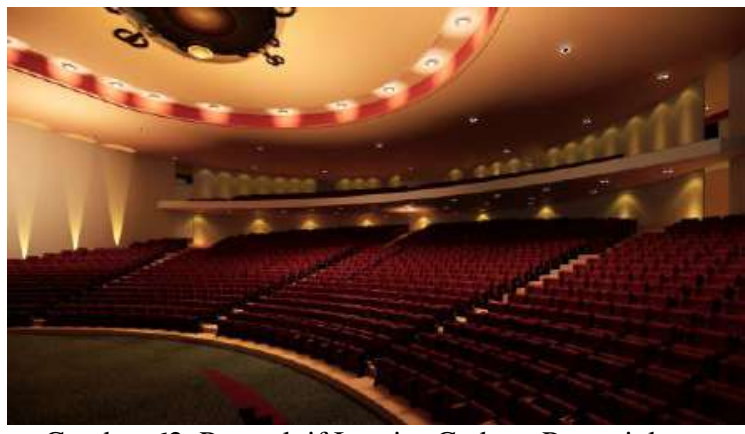

Gambar 62. Perspektif Interior Gedung Pertunjukan

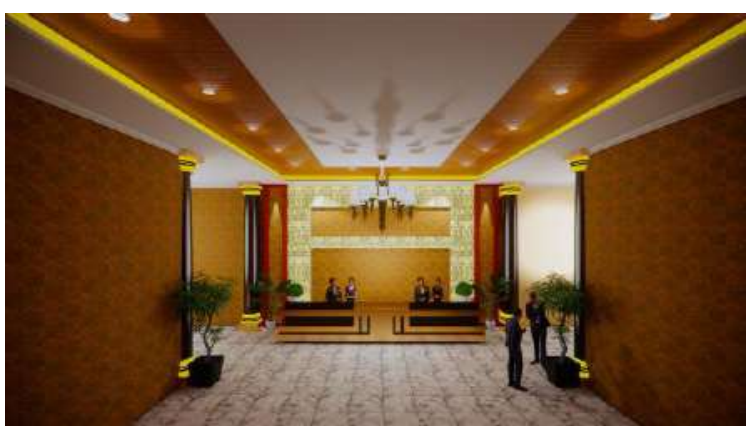

Gambar 63. Perspektif Interior Resepsionis Hotel 


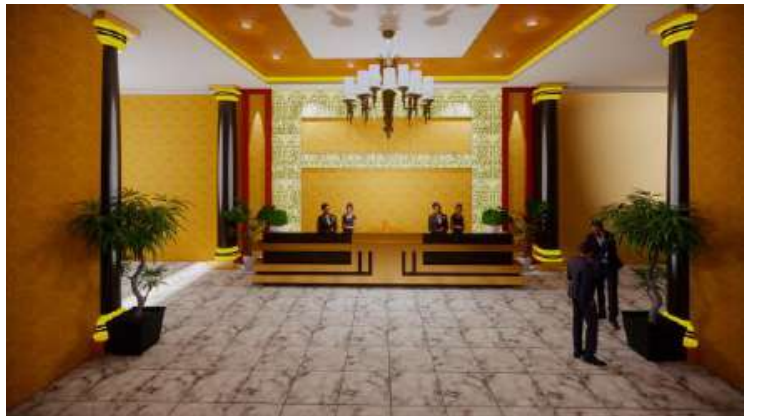

Gambar 64. Perspektif Interior Resepsionis Hotel

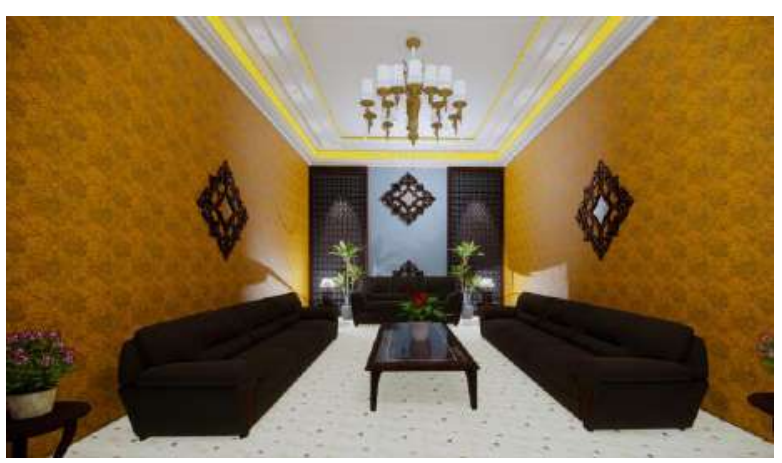

Gambar 65. Perspektif Interior Ruang Tunggu

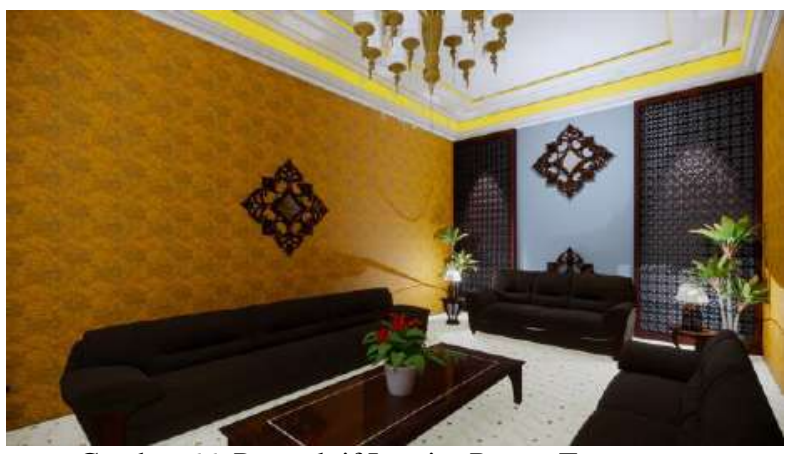

Gambar 66. Perspektif Interior Ruang Tunggu

Anonim. (2016).

Fungsi dan desain arssitektur gedung pertunjuka seni

Anonim. (2016).

Miaesarch work

Anonim. (2016).

Architizle idea

Anonim. (2017)

pengertian gedung pertunjukan dan jenisnya

Anonim. (2018).

Ciputra artpreneur jakarta.

Anonim (2018).

Gedung kesenian jakarta.

Anonim. Rancangan gedung pertunjukan seni

Adisamito.(2020).jurnalunpand pola penatan ruang dan sirkulasi pengunjung gedung pertunjukan seni.

Sayamsudin sidiq. (2015).

Standart usaha gedung pertunjukan seni

Widya novia (2016).

Persiapan tugas akhir pola penataan ruang gedung pertunjukan

https://www.99.co/blog/indonesia/gayaarsitektur-klasik/

\section{DAFTAR PUSTAKA}

Anonim. (2014).

Great amber concert hall. Eu. Europa. Eu.

Investeu.

Anonim. (2014).

Great amber concert hall. Eu. Europa. Eu.

Regional.

Anonim.(2015).

Encrypted gedung kesenian jakarta.

Anonim. (2015).

Great amber concert hall. Volkar giencke

Anonim. (2015).

Great amber concert hall.

Anonim. (2015).

Great amber concert hall. Arc.gaily

Anonim. (2016).

Great amber concert hall. Aecafe showcase 